\title{
2 A Map of Orientations to the Teaching of the Bible ${ }^{1}$
}

\author{
Barry W. Holtz
}

If we were to ask any educated person to name the qualities most associated with being "a good teacher," one of the first things mentioned would be that a good teacher needs to know the subject matter. But in that simple phrase rests a great deal of complexity. What does it really mean to "know the subject matter"? And how does knowing the subject matter help the individual be a good teacher? Over the past twenty-five years, education researchers have been grappling with these questions, trying to make sense of the relationship between subject matter knowledge and good teaching.

Pamela Grossman, one of the scholars in general education whose work is most relevant to Jewish education, has looked carefully at the importance of a teacher's knowledge of subject matter for the teaching of English literary texts, and her work can be usefully applied to understanding the teaching of classical Jewish texts as well. Her approach to teacher knowledge, focusing as it does on "pedagogical content knowledge," goes beyond the approach to subject-matter knowledge that characterized earlier research on teachers and teaching, which "found little or no relationship between teachers' subject-matter knowledge and either pupil achievement or general teaching performance."3 As Grossman points

1 This chapter is a condensed and revised version of chapter three of Barry W. Holtz, Textual Knowledge: Teaching the Bible in Theory and in Practice (New York: JTS, 2003).

2 This term is most associated with Lee Shulman and his former students, one of whom is Pamela Grossman. See Shulman's “Those Who Understand: Knowledge Growth in Teaching," Educational Researcher 15, no. 2 (1986): 4-14. Also see Pamela Grossman, "What Are We Talking About Anyhow? Subject-Matter Knowledge of English Teachers," in Advances in Research on Teaching, ed. J. Brophy (JAI: Bingley, UK, 1991), 2:245-64; Pamela L. Grossman, Suzanne M. Wilson, and Lee S. Shulman, "Teachers of Substance: Subject-Matter Knowledge for Teaching," in Knowledge Base for the Beginning Teacher, ed. M. Reynolds (New York: Pergamon, 1989), 23-36.

3 Grossman, "What Are We Talking About Anyhow?" 258. 
out, these findings may "tell us as much about our difficulties in conceptualizing the role of subject-matter knowledge in teaching as about the relationship between knowledge and teaching itself."

Far more significant for teaching than how many courses in the subject one took in college, or how much information one knows about the subject matter, is what Grossman calls a teacher's "orientation" to the subject matter being taught. Grossman uses "orientation" as an inclusive term that encompasses Joseph Schwab's notions of the "substantive" and "syntactic" structures of a discipline, referring respectively to the interpretive frames or lenses through which the entire field is understood, ${ }^{5}$ and the tools that scholars use to introduce new knowledge to a field and the canons by which evidence is viewed as acceptable or not. ${ }^{6}$ Grossman, however, adds an important dimension to Schwab's emphasis on knowledge by recognizing the importance of teachers' beliefs about the subject matter as well, "since it is frequently the case that teachers treat their beliefs as knowledge." Unlike knowledge, "beliefs rely heavily on affective and personal evaluations" ${ }^{8}$ of teachers, and include matters such as teachers' deep, underlying commitments and their sense of how students learn best and why the subject matter itself is important to study.

"Orientation," as a term, then, encompasses aspects of both the knowledge and belief sides of a teacher's relationship to the subject matter. An orientation represents teachers' "interpretive stance ... toward literature [and] becomes important in understanding their goals for instruction, curricular choices, instructional assignments, and classroom questions." "More than a casual attitude towards the subject matter, an orientation towards literature represents a basic organizing framework for knowledge about literature"10 — and, Grossman further explains, for teaching it. And while teachers who have not explored the structures

4 Ibid.

5 Joseph J. Schwab, "Education and the Structure of the Disciplines" (1961), in his collected essays, Science, Curriculum, and Liberal Education, ed. Ian Westbury and Neil J. Wilkof (Chicago: University of Chicago Press, 1978), 246.

6 Ibid.

7 Grossman et al., "Teachers of Substance," 31.

8 Ibid.

9 Grossman, "What Are We Talking About Anyhow?" 247.

10 Ibid., 248. 
of their discipline are at a great disadvantage in thinking about how to teach that discipline to others-as Schwab puts it, "To know what structures underlie a given body of knowledge is to know what problems we shall face in imparting this knowledge" 11 - a teacher who has not confronted his or her underlying assumptions, prejudices, emotions, and aims about the subject matter will also teach much less effectively.

\section{Orientations for Teaching Bible}

An orientation, then, is no less than a real-life actualization of a teacher's underlying beliefs and pedagogic goals. How might we begin to apply in a specific way the idea of orientations to the teaching of Bible? If we begin in the world of the university, we find no simple answer to the question, "What are the appropriate orientations for Bible teaching?" Such orientations need to be rooted in the approaches to the study of Bible evidenced in the university, and the contemporary academic landscape is dotted with various methods of biblical scholarship, each of which might serve as a starting point for a pedagogy of Bible. In the words of one scholar,

As recently as two decades ago, there was a consensus among scholars about using a fairly limited number of critical methods for the study of Bible, but today the spectrum of methods employed has enlarged dramatically.... How these different methods of biblical inquiry are to be related logically and procedurally has become a major intellectual challenge that will require a comprehensive frame of reference not readily at hand. ${ }^{12}$

These words, written by Gottwald in 1985, are even more true today, when the modes of biblical criticism encompass a variety of approaches even more varied than those of twenty-five years ago.

Certainly, it is not my intention here to attempt the synthesis of methods advocated by Gottwald above, or even to present a compre-

11 Joseph J. Schwab, "Structure of the Disciplines: Meanings and Significances," in The Structure of Knowledge and the Curriculum, ed. G. W. Ford and Lawrence Pugno (Chicago: Rand McNally, 1964), 13.

12 Norman K. Gottwald, The Hebrew Bible: A Socio-Literary Introduction (Philadelphia: Fortress, 1985), 7. 
hensive catalog of such methods. Whether one would use Gottwald's own "angles of vision," Edward L. Greenstein's contrast of "synchronic" and "diachronic"13 approaches to text, or the various attempts to organize contemporary literary approaches, ${ }^{14}$ such a task is large and well beyond the scope of this chapter. By way of illustration, one need only consider that even within the "literary" mode alone, we could begin with examples of classic "source criticism" and "form criticism," and continue all the way through present-day feminist, psychoanalytic, or political criticism, and many others as well. "Historical" approaches to the Bible also vary widely. In this area, for example, feminist works such as Meyers's Discovering Eve stand side by side with older approaches such as Noth's The Old Testament World,${ }^{15}$ with a great range in between.

What I wish to do here instead is to take a stance appropriate to an educational perspective: namely, to consider which methods of biblical research often serve as a basis for pedagogy. Following upon that discussion, I will turn to other approaches to the teaching of Bible, orientations that are less likely to be associated with the university and have their roots in the "wisdom of practice" of teachers and in various ideological or philosophical stances unrelated to the "scientific" study of the Bible. Ultimately, a map of various orientations to teaching Bible will emerge.

\section{Two Bible Teachers: The Contextual and Literary Orientation}

Let us first imagine two different teachers of Bible. How might they orient themselves vis-à-vis their subject matter? How might they prepare lessons for students-either adults or children? What grounds their educational thinking and pedagogic approaches?

13 Ibid.; see, in particular, 32-38.

14 Such as those offered in The New Literary Criticism and the Hebrew Bible, ed. J. Cheryl Exum and David J. A. Clines (Sheffield, England: Sheffield Academic Press, 1993). For an overview of various approaches, see Steven L. McKenzie and Stephen R. Haynes, eds., To Each Its Own Meaning (Louisville: Westminster John Knox, 1999). Also, Walter C. Kaiser and Moises Silva, An Introduction to Biblical Hermeneutics: The Search for Meaning (Grand Rapids, MI: Zondervan, 1994).

15 Carol Meyers, Discovering Eve (Oxford: Oxford University Press, 1988); Martin Noth, The Old Testament World (Philadelphia: Fortress, 1966). 
David became interested in the Bible while spending his junior year of college in Israel. He was profoundly touched by the connection of the landscape of the Bible to the land he was literally walking on. He delighted in visiting archaeological sites, began reading books about the Ancient Near East, and started to view the Bible as a living repository of the history of his people. The realia, the ancient cultures and languages, and the laws of ancient Israel and their comparison with neighboring laws and practices fascinated him. When David returned from Israel, he began to take religion courses at his university, and found that most of his professors were similarly oriented in their approach to Bible. He pored over copies of the magazine Biblical Archaeology Review and even began to study Ugaritic, one of the ancient Semitic languages so important in biblical research.

In preparing his teaching, David found commentaries such as the Anchor Bible and the Jewish Publication Society Commentary on the Torah to be very useful. ${ }^{16}$ For a class he was teaching at his local synagogue, David turned to one of the most popular and influential works about the Bible, Nahum Sarna's Understanding Genesis. Originally published by the Jewish Theological Seminary's Melton Research Center in 1966, Sarna's book was one of the first to bring "to the general reader a body of essential knowledge, the distillation and integration of the results of specialized research in many varied disciplines that shed light upon the biblical text." ${ }^{\prime 17}$

David wishes to show his students the world of biblical people, what they believed and felt, how they lived, and what they valued. He admires Sarna's emphasis on "the importance of difference [and] those areas in which Israel parted company with its neighbors." ${ }^{18}$ David brings to his students lessons that compare the Bible's creation story with the creation myths of other ancient cultures.

16 The Anchor Bible series comprises many volumes, all published by Doubleday in New York, over the course of over three decades. The JPS (of Philadelphia) Torah Commentary appears in five volumes: Nahum M. Sarna on Genesis (1989), Sarna on Exodus (1991), Baruch A. Levine on Leviticus (1989), Jacob Milgrom on Numbers (1990), and Jeffrey H. Tigay on Deuteronomy (1996).

17 Nahum M. Sarna, Understanding Genesis (New York: Melton Research Center and Schocken Books, 1966), xxxiii.

18 Ibid., xxvii. 
David is preparing to teach the Joseph story. Looking in Understanding Genesis, he notes Sarna's explanations of the text: the "coat of many colors," David learns, was "a token of special favor and perhaps, too, of luxury and lordship"; 19 David sees the meaning of Joseph's dreams "against the background of the times"; ${ }^{20}$ he reads about the situation of slavery in ancient Egypt; ${ }^{21}$ and he explores the comparison of the attempted seduction of Joseph in Genesis 39 to the "Tale of Two Brothers" (an ancient story). ${ }^{22}$ All the data that David draws from Sarna's book allow David to focus and enrich the lessons he prepares.

Let us imagine, now, a different teacher. Sarah was a literature major in college. She cares about the close reading of literary works and sees her role as helping to guide students along the path of careful textual analysis. The literary critical approaches to fiction and poetry that she learned in college have influenced her thinking and beliefs about being a Bible teacher. But when she began to examine "literary" approaches to the study of Bible, she was astonished to find that most of the works she consulted took a completely different view of the word "literary"-in essence, taking the biblical work apart through a variety of scholarly methods rather than reading it as a whole and appreciating it as literature and a source of meaning. In the words of Kenneth Gros Louis, "What has been called 'literary criticism' of the Bible is not the kind of literary criticism teachers of literature do. In fact, the biblical scholar's definition of 'literary criticism' is virtually the opposite of the literary critic's." ${ }^{23}$ Sarah, however, has come upon Robert Alter's The Art of Biblical Narrative, and his approach is exactly what she was looking for: an approach of literary analysis of the Bible, which the author describes as

the manifold varieties of minutely discriminating attention to the artful use of language, to the shifting play of ideas, conventions, tone, sound, imagery, syntax, narrative viewpoint, compositional units, and much else; the kind of disciplined attention, in other

19 Ibid., 212.

20 Ibid.

21 Ibid., 213.

22 Ibid., 214-15.

23 Kenneth R. R. Gros Louis, "Some Methodological Considerations," in Literary Interpretations of Biblical Narratives, ed. Kenneth R. R. Gros Louis with James S. Ackerman (Nashville: Abingdon, 1982), 2:14. 
words, which through a whole spectrum of critical approaches has illuminated, for example, the poetry of Dante, the plays of Shakespeare, the novels of Tolstoy. ${ }^{24}$

Sarah has also read an article by Gros Louis and finds his set of "questions a literary critic considers in approaching a work of literature" 25 very much what she wants her students to consider in her classes: questions about the literary structure, style, tone, and characters' motivations, among others. An article by Joel Rosenberg ${ }^{26}$ helps her understand the particular features of biblical narrative, and she wants to help her students recognize these features and how they function in conveying the story's meaning.

Unlike David, Sarah is not particularly interested in the Ancient Near East and the historical background to the Bible. Using a term from Alter, Sarah characterizes the approach that her fellow teacher David admires as being "excavative" (she would say "merely excavative!"); that is, "either literally, with the archaeologist's spade and reference to its findings, or with a variety of analytic tools intended to uncover the original meanings of biblical words, the life situations in which specific texts were used, the sundry sources from which longer texts were assembled."27 She, in contrast, wants her students to primarily "read the text as it is," as she likes to put it, not as it may have been understood in ancient times. In the mode of the New Critics, Sarah wants the text "treated as a privileged object that should be considered predominantly in its own terms with contextual factors being assigned a minor role." 28

Like David, Sarah is preparing to teach a unit on the Joseph stories in Genesis, and she finds Alter's reading of the text particularly helpful. His suggestion about the literary artistry of the tale will help guide the way Sarah structures her lessons. In his reading of Genesis 42, Alter points out the following, for example:

24 Robert Alter, The Art of Biblical Narrative (New York: Basic Books, 1982), 12-13. Gros Louis, "Some Methodological Considerations," 17. His "questions" appear on 17-20.

26 Joel Rosenberg, "Biblical Narrative," in Back to the Sources: Reading the Classic Jewish Texts, ed. Barry W. Holtz (New York: Simon and Schuster/Summit, 1984), particularly 37-62.

27 Alter, The Art of Biblical Narrative, 13.

28 K. M. Newton, Interpreting the Text (New York and London: Harvester Wheatsheaf, 1990), 174. 
The narrator, as we have noted, began the episode by emphatically and symmetrically stating Joseph's knowledge and the brothers' ignorance. Now, through all this dialogue, he studiously refrains from comment, allowing the dynamics of the relationship between Joseph and his brothers to be revealed solely through their words, and leaving us to wonder in particular about Joseph's precise motives. Whatever those may be, the alertness to analogy to which biblical narrative should have accustomed us ought to make us see that Joseph perpetrates on the brothers first a reversal, then a repetition, of what they did to him. ${ }^{29}$

This passage from Alter's analysis helps Sarah envision what she wants to concentrate on, what worksheets she might design for individualized learning, and what focusing questions she will ask in the whole-class discussions. Her goal is to prepare readers of the Bible as literature, in the spirit of Alter and the other, newer, interpreters of Bible whom she has subsequently discovered. ${ }^{30}$

In David and Sarah, we have paradigms of teachers with two different academic approaches to Bible: what we might call the historical or contextual orientation, and the classic modernist literary analysis. The contextual approach aims at uncovering the meaning of the biblical texts by viewing the Bible within the context of its own times, as best as we can determine it. It views the Bible as a record of an ancient civilization, and it hopes to make that world intelligible to students of today. This is the mode of Bible study that has most characterized the modern university,

29 Alter, The Art of Biblical Narrative, 165-66.

30 There are many works that a teacher like Sarah could turn to for help. Aside from the writers already mentioned in this article and just limiting the list to books in English, she would find the readings in the following of great pedagogic assistance: Michael Fishbane's discussion of both narrative and poetry in Text and Texture (New York: Schocken, 1979); Meir Sternberg's The Poetics of Biblical Narrative (Bloomington: University of Indiana Press, 1985); George Savran's Telling and Retelling (Bloomington: University of Indiana Press, 1988); Mieke Bal's Lethal Love (Bloomington: University of Indiana Press, 1987); and Herbert Levine's readings of Psalms in his Sing Unto God a New Song (Bloomington: University of Indiana Press, 1995). In addition, there is the marvelous translation of the Pentateuch in English, based on the Buber-Rosenzweig German version, done by the American scholar Everett Fox, with its excellent commentaries, The Five Books of Moses (New York: Schocken, 1995). 
at least until quite recently. This orientation to teaching Bible has also been very influential in the secular school system in Israel, though much less so in the Diaspora. ${ }^{31}$ It should be noted that the contextual approach includes a variety of dimensions, including the use of various tools that help locate the Bible in its historical setting. These might include source criticism (looking at the strands of tradition that come together to form the biblical text as we know it, that is, the "documentary hypothesis"), form criticism (looking at all the formal patterns within and among texts), comparative linguistics (understanding the language of the Bible through looking at other languages that are linguistically related), and archaeology, among others.

Sarah's orientation, which we will call the literary criticism orientation, aims at literary readings of biblical texts, using the tools of modern literary analysis. There is a wide range of approaches within this domain, but most pay careful attention to the style, language, characters, themes, and forms of the biblical text. Such approaches are far more commonly used with biblical narratives and poetry than legal, prophetic, or wisdom-literature sections of the Bible. This orientation includes "post-modern" approaches to hermeneutics, most specifically in its use of "reader-response" criticism. What characterizes readerresponse reading is that it focuses on the experience of the reader in encountering the text-what happens to the reader, and how the text itself is structured to affect the reader. Post-modern approaches to literary theory includes a wide range of other ways to read texts; perhaps the best-known is feminist criticism, which in its various manifestations focuses on the representations of female characters and on legal passages related to women in the Bible, reads the biblical text through a feminist lens, and places gender at the center of one's reading (and teaching). It includes the work of such scholars as Carol Meyers (see note 15), Mieke Bal (see note 30), Alice Bach, J. Cheryl Exum, Phyllis Trible, and Tikvah Frymer-Kensky, among many others. ${ }^{32}$

31 See Barry W. Holtz, "Teaching the Bible in Our Times," in International Handbook of Jewish Education, ed. Helena Miller, Lisa Grant, and Alex Pomson (New York: Springer, 2012).

32 See Alice Bach, Women in the Hebrew Bible: A Reader (New York: Routledge, 1998) and her Women, Seduction, and Betrayal in Biblical Narrative (Cambridge: Cambridge University Press, 1997); J. Cheryl Exum, Fragmented Women: Feminist Subversions of Biblical Narratives (Harrisburg, PA: Trinity Press Interna- 


\section{Parshanut: Traditional Bible Commentaries}

Of course, contextual and literary approaches to the Bible do not exhaust the ways that the Bible is both studied and taught. One obvious next approach is the study of Bible in the light of its classical Jewish commentaries. The use of traditional commentaries in Jewish education emanates from a deep assumption embedded in the tradition that this literature of commentary is part of Torah; ${ }^{33}$ for centuries, the interpretations of the traditional commentaries were understood as the authoritative Jewish understanding of the Bible.

Of course, one of the features of the Jewish interpretive literature from its beginnings to the present day is that there is no one authoritative understanding of the text, but rather a range of views. As one scholar has put it, "the characteristic of early rabbinic commentary that is most distinctive ... [is] its multiplicity of interpretations." ${ }^{34}$ Educationally, it is possible for the teacher to view this range of interpretations as something to be embraced or something to be avoided. That is, a teacher may choose to limit the students' access to this range by presenting the tradition as if there is only one authoritative view (this is typical of the way Rashi, the great medieval commentator, is used in some Orthodox schools), but others see presenting divergent views within the tradition as one of the goals of learning itself. Perhaps the most well-known exponent of the latter approach is the late professor Nehama Leibowitz, who,

tional, 1993); Phyllis Trible, Texts of Terror: Literary-Feminist Readings of Biblical Narratives (Philadelphia: Fortress Press, 1984); Tikvah Frymer-Kensky, Studies in Bible and Feminist Criticism (Philadelphia: Jewish Publication Society, 2006). More popular representations of feminist approaches to reading the Bible include: Elyse M. Goldstein, The Women's Torah Commentary: New Insights from Women Rabbis on the 54 Weekly Torah Portions (Woodstock, VT: Jewish Lights Publishing, 2008); and Tamara Cohn Eskenazi and Andrea Weiss, eds., The Torah: A Women's Commentary (New York: URJ Press, 2007).

33 This idea is discussed in numerous places in the religious and scholarly literature. See, for one example, the well-known essay by Gershom Scholem "Revelation and Tradition as Religious Categories in Judaism," in his The Messianic Idea in Judaism (New York: Schocken, 1971), 282-304. Or Jacob Neusner, The Oral Torah (Atlanta: Scholars Press, 1991).

34 Steven D. Fraade, From Tradition to Commentary (Albany: State University of New York Press, 1991), 15. See also his interesting notion of a "circulatory view" of rabbinic commentary, on pp. 19-20. 
over the course of decades, focused on classic biblical commentaries in both her classes and her numerous writings. ${ }^{35}$

The basis for Leibowitz's approach was much less the academy's method of biblical research than it was a classic Jewish religious perspective to approaching the text through its commentaries. Leibowitz was not a historian who focused on the historical or intellectual context of the commentator, as university scholars might; she was interested in the commentator as a window onto the Bible itself, or onto the way we should understand the Bible. ${ }^{36}$ She was committed to a "close reading" of the biblical text-in a sense, occupying the place where traditional reading and modern literary criticism meet. Her approach emanates directly out of the oldest notions of Jewish Bible interpretation, something that James Kugel has characterized as "the doctrine of 'omnisignificance,' whereby nothing in Scripture is said in vain or for rhetorical flourish: every detail is important, everything is intended to impart some teaching." ${ }^{37}$ Yet despite the shared use of close reading, modern literary criticism and traditional biblical interpretation are at heart quite different enterprises, based on different foundational assumptions and beliefs about the text. ${ }^{38}$

A typical example of Leibowitz's method is found in her approach to the early part of the Joseph story. (Leibowitz offers a number of different "studies" for this story; I am only choosing one.) She explores the puz-

35 For an analysis of Leibowitz's work, see Marla L. Frankel, Teaching the Bible: The Philosophy of Nechama Leibowitz (Tel Aviv: Miskal-Yedioth Ahronoth Books and Chemed Books, 2007) [in Hebrew]. Also: Howard Deitcher, "Between Angels and Mere Mortals: Nehama Leibowitz's Approach to the Study of Biblical Characters," Journal of Jewish Education 66, 1-2 (Spring/Summer 2000): 8-22; and Joy Rochwarger, "Words on Fire: Then and Now-In Memory of Nechama Leibowitz," in Torah of the Mothers, ed. Ora Wiskind Elper and Susan Handelman (New York and Jerusalem: Urim, 2000), 57-80.

36 A good example is the scholarly study by Jeremy Cohen, Be Fertile and Increase, Fill the Earth and Master It: The Ancient and Medieval Career of a Biblical Text (Ithaca, NY: Cornell University Press, 1989).

37 James L. Kugel, The Bible as It Was (Cambridge, MA: Belknap Press of Harvard University Press, 1997), 21. Also see my discussion in Holtz, Back to the Sources, 177-212.

38 See the excellent discussion of this issue by Robert Alter in "Old Rabbis, New Critics," The New Republic, 5 \& 12 (January 1987): 27-33. Also my "Midrash and Modernity: Can Midrash Serve a Contemporary Religious Discourse?" in The Uses of Tradition, ed. Jack Wertheimer (New York: Jewish Theological Seminary, 1992). 
zling section in Genesis 37:28 in which Joseph is sold into slavery either by "Midianites" or "Ishmaelites," or, as the text says later, by "Medanites." Her method is to look at the understandings of this confusing narrative by a variety of medieval commentators, with reference back to the midrashic literature and forward to more modern, though nonetheless traditional, commentators such as Samson Raphael Hirsch and Benno Jacob. Whereas Sarna, using a historical/contextual approach, will point out that the "variation may well be due to an interweaving of different traditions" 39 and Greenstein (in the article discussed above) will look at the effect on the reader of the textual ambiguity, Leibowitz is interested in the way traditional commentators dealt with the problem and what they expressed about the Bible through their respective solutions.

With a careful eye to the implications of each of the commentator's views, Leibowitz asks, in typical fashion: "But the main question is how does this new interpretation affect the significance of the story as a whole?"40 This question stands behind much of her work and explains a good deal of why her writing is so attractive to educators ${ }^{41}$-Leibowitz aims immediately for the significance of the text. We will term this orientation, typified by Leibowitz, the parshanut or Jewish interpretive approach, and with this example we have moved outside the warrant of the academy into other educational justifications for teaching practice.

For teachers (and scholars) in general education, the overarching criterion of authority is the world of the university and its culture, rules, and modes of discourse, but in Jewish education, the authority of the discipline resides in multiple locations, not all of which are within the university. For the traditionalist yeshiva teacher, for example, the meaning of the text is what the classical commentators reveal it to be. And the Bible is God's word, not a human document, and the way university scholars might talk about the genres and subgenres of the Bible-narrative, law, prophecy, and so on-is unimaginable; the Bible is not a collection of different types of literature but a seamless whole. In the

39 Sarna, Understanding Genesis, 214.

40 Leibowitz, Studies in Bereshit, 407.

41 Her written materials are also eminently usable. One can easily imagine a teacher taking Leibowitz's chapter, photocopying the various excerpts from the commentators, and basing his or her lesson around an exploration of these texts. Even the questions that Leibowitz appends to each "study," written originally for the students themselves, are well suited for a teacher's use. 
realm of Jewish religious education, then, we see the reality of multiple approaches to the discipline, some of which are governed by the rules of university discourse and others of which are quite different ${ }^{42}$ - so different, in fact, that even the word "discipline" is outside the realm of their discourse. We might refer here to the notion of "interpretive communities" of textual interpretation, as it appears in the work of the literary critic Stanley Fish. That is, the way we read texts - and, in our case, the way we teach texts - is deeply connected to the community to which we belong. Fish claims that the "interpretive strategies" employed by individual readers "exist prior to the act of reading and therefore determine the shape of what is read rather than, as is usually assumed, the other way around." 43 We live in communities that help us understand texts, what we want to accomplish when we teach them, where we see ourselves, and where we see our students and their futures.

Any particular teacher's orientation toward teaching a text (or indeed, toward any pedagogic situation, such as teaching mathematics) emanates, it appears, from a combination of at least three sources: a) the particular personality and temperament of the teacher him- or herself; ${ }^{44}$ b) the available authoritative models of one's milieu or culture (i.e., one's "interpretive community"); and c) the "wisdom of practice," 45 as it

42 For a related issue, see Jonathan Cohen's discussion of the problem of defining Jewish philosophy as a discipline in his "Enacting the Eclectic: The Case of Jewish Philosophy," Journal of Curriculum Studies 30, no. 2 (1998): 207-31. Stanley Fish, Is There a Text in This Class?:The Authority of Interpretive Communities (Cambridge, MA: Harvard University Press, 1980), 171.

44 There is a good deal of research currently available on the relationship of a teacher's biography and his or her way of teaching. See, for example, Freema Elbaz, Teaching Thinking: A Study of Practical Knowledge (London: Croom Helm, 1983); P. S. Millies, "The Relationship between a Teacher's Life and Teaching," in Teacher Lore: Learning from Our Experience, ed. William H. Schubert and William Ayers (White Plains, NY: Longman, 1992); F. Michael Connelly and D. Jean Clandinin, "Personal Practical Knowledge and the Modes of Knowing," in Learning and Teaching the Ways of Knowing, ed. Eliot Eisner, 84th Yearbook of the National Society for the Study of Education (Chicago: University of Chicago Press, 1985), 174-98; Marilyn Cochran-Smith and Susan L. Lytle, eds., Inside/Outside: Teacher Research and Knowledge (New York: Teachers College Press, 1992); and Rosetta Marantz Cohen, A Lifetime of Teaching: Portraits of Five Veteran High School Teachers (New York: Teachers College Press, 1991).

Shulman, "Those Who Understand." 
has been experienced by the teacher, either in his or her own career or in knowing about the practices of other teachers. (Some of those models may be colleagues, the teachers of one's own youth, ${ }^{46}$ and/or those who transmit their "wisdom" through books and articles.) The teacher in this view "is not only a master of procedure but also of content and rationale ... capable of explaining why something is done." 47 Teachers, then, have their own views about what should be done in the classroom, based on their sense not merely of what works but also of what is worth doing.

\section{Looking for a Moral}

But how might wisdom of practice be investigated? Aside from observing teachers at work in classrooms or interviewing them, perhaps the best way to understand wisdom of practice is to look at the curriculum materials actually used by teachers as an indication of the way they may approach their particular subjects. Certainly it is true that decisions about the books that a class uses are not in the hands of teachers alone. But the popularity of certain books-and the way that those books attempt to reflect the actual practices of teachers-makes looking at textbooks a valuable and instructive exercise. ${ }^{48}$

If we turn to one popular example, an orientation to the teaching of Bible different from what we have seen up to now becomes apparent. A Child's Bible, by Seymour Rossel, aims to look at the narratives in the Bible as a means of instructing us today in the way we should behave. "The people in the stories," we read in the introduction for the student, "are always a lot like us. So the stories help us learn how we should live, what we should do, and how we should behave." ${ }^{\text {99 }}$ The aim is to see "what

46 Through the "apprenticeship of observation" that all teachers experience-by having been students themselves. See Dan Lortie, Schoolteacher (Chicago: University of Chicago Press, 1975).

47 Shulman, "Those Who Understand," 13.

48 See Miriam Ben-Peretz, The Teacher-Curriculum Encounter: Freeing Teachers from the Tyranny of Texts (Albany: State University of New York Press, 1990), on the potential of curriculum and its limitations; and for some of the difficulties, Sharon Feiman-Nemser and Deborah Loewenberg Ball, "Using Textbooks and Teachers' Guides: A Dilemma for Beginning Teachers and Teacher Educators," Curriculum Inquiry 18 (1988): 401-23.

Seymour Rossel, A Child's Bible (West Orange, NJ: Behrman House, 1988), 7. 
[the stories] mean to us today," and in order to do so, students should ask themselves: "What truth is this story teaching me?' 'What does this story say that I should do?' 'How does this story say that I should behave?"'50

We see this method exemplified in the textbook's explanation of the Joseph story, in a discussion that includes, under "What does it mean": "Your dreams teach you things you need to know. Even a bad dream can help you grow stronger." ${ }^{1}$ And under "What does it teach" (the distinction between this and "What does it mean" is not entirely clear to me):

Joseph heard Pharaoh say that there were two dreams. But he listened very carefully. And that is how he discovered that both were really one and the same dream. If you want to help people by listening to them, you must first listen to their words. But then you must also try to hear what their words mean. Joseph was a good listener. ${ }^{52}$

The biblical stories, according to this view, are important for the moral lessons that they communicate. Unlike the academic literary methodand the pedagogic approach that emanates from it-which aims at opening up the complexity, indeed, the ambiguity, of the biblical narrative, A Child's Bible is oriented toward simplifying the biblical tale into a specific "teaching," as Rossel puts it in his introduction. Contrast this with Alter's comment that "an essential aim of the innovative technique of fiction worked out by the ancient Hebrew writers was to produce a certain indeterminancy of meaning, especially in regard to motive, moral character, and psychology." 53 Perhaps for this reason, A Child's Bible does not use the actual biblical text itself (filled with the many ambiguities that contemporary Bible scholars delight in pointing out), but rather retells the stories, leaving out the inconvenient complexities of the original and adding clarifying points on its own.

The underlying assumption of this approach is that the Bible communicates clear lessons, and the details of the narratives are to be understood as pointing us in the way of good moral behavior. Educationally,

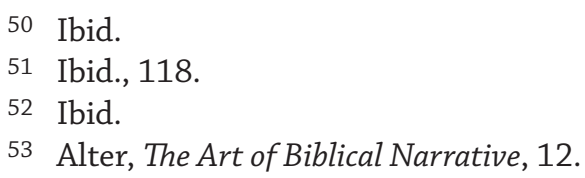


A Child's Bible has the advantage of being accessible to children and clear about its outcomes. The Bible, in these lessons, has something to tell us, and in each case we will be able to define what that something is (or what those somethings are). Children can take home these messages and feel that the Bible speaks to them. ${ }^{54}$

We might characterize the orientation of $A$ Child's Bible as a "didactic" or "moralistic" approach to Bible. Although A Child's Bible is aimed at the more liberal sector within Jewish religious practice, it ironically resembles approaches seen in more traditional communities, such as that found in the series of textbooks called Gateway to Torah..$^{55}$

Although the moralistic approach focuses on finding the meanings of the biblical text, it differs from the literary orientation in at least two ways. First, as I mentioned above, the didactic orientation eschews the literary orientation's close reading of the text with its consequent emphasis on the nuance and specific vocabulary and tone of the biblical text, replacing close reading with an expanded retelling of the narrative. Second, it aims to extract a specific kind of message from the text. A literary method is never about uncovering a message to learn, though people may certainly learn such messages from their reading of texts. We don't expect a person to read Hamlet and say that the moral of the story is "don't be wishy-washy about making decisions," or "don't listen to ghosts when they give you missions." Indeed, these comical attempts to sum up the play indicate exactly the nature of the problem: great literary works are admired for their complexity, their ability to mirror the complexity of life itself, perhaps, and not because we can learn a simple lesson from them. Hence, no one puts Oedipus Rex and Aesop's fable of "The Fox and Grapes" at the same level of literary accomplishment. In the same spirit, Rosenberg speaks about the nature of the biblical narrative:

[I]t is impossible to distill the message of biblical narrative. Attempts to generalize yield only moral and theological truisms that do violence to the Bible's special way of talking. Biblical narrative rarely moralizes. It explores moral questions, to be sure, but it is in the wit and nuance of the specific moment that one is to find

54 Alter and others would no doubt argue that such an educational approach sends a not-so-hidden message that the Bible is simple, perhaps even simplistic. The Bible becomes a kind of Jewish Aesop's Fables.

55 Miriam Lorber and Judith Shamir, Gateway to Torah (New York: Ktav, 1991). 
the narrative's intelligence most concentrated. This intelligence steadfastly withholds itself from stating "messages." It allows its messages to arise from silences in the narrative. In a sense, it is weighing messages, in that discordant voices in the tradition are allowed silently to clash, even as the narrative plunges inexorably forward. ${ }^{56}$

Neither this approach nor a didactic or moralistic approach aims at confronting the issue of the personal meaning of the text in the life of the reader. The teacher who uses the didactic orientation attempts to teach moral messages applicable to all students. The teacher who uses a literary orientation understands that although the student may uncover many meanings in the biblical text, none need address his or her own experience or life. A teacher operating strictly within either orientation will not ask the student, "Well, what does this mean to you?" For that, we need to turn to another orientation, what I call "personalization."

\section{Personalization and Bible Teaching}

In the twentieth century, perhaps the most powerful representation of the personalization orientation to the Bible comes from Martin Buber. In his essay "The Man of Today and the Jewish Bible," Buber tries to articulate a way for us to encounter the Bible directly in our lives. ${ }^{57}$ Too often, Buber says, people today view the Bible in a distant, "abstract" way with "an interest connected with the history of religion or civilization, or an aesthetic interest, or the like-at any rate it is an interest that springs from the detached spirit" 58 of contemporary life. We picture Buber watching our friend David teach, as he uses his "contextual" orientation; we imagine Buber observing Sarah's lessons as she explores the literary "aesthetic" of the biblical text. Neither satisfies

56 Rosenberg, "Biblical Narrative," 62-63.

57 In Martin Buber, On the Bible: Eighteen Studies, ed. Nahum N. Glatzer (New York: Schocken, 1968). Note Buber's influence on a more recent book, Gabriel Josipovici's The Book of God: A Response to the Bible (New Haven: Yale University Press, 1988), in which the author says that we should look at the Bible not "as a book to be deciphered, or a story to be told," but rather, "we should think of it as a person. We do not decipher people, we encounter them" (307).

58 Buber, "Man of Today," 4. 
Buber; both seem too safe, neither "confronts ... life with the Word." Instead, Buber argues for another course. The "man of today," Buber says,

can open up to this book and let its rays strike him where they will.... He can absorb the Bible with all his strength, and wait to see what will happen to him....

He must yield to it, withhold nothing of his being, and let whatever will occur between himself and it. He does not know which of its sayings and images will overwhelm him and mold him, from where the spirit will ferment and enter into him.... But he holds himself open. ${ }^{60}$

This remarkable passage could well serve as the defining motto of personalization in regard to reading and teaching the Bible. Certainly, it is not easy to picture exactly what it means to translate it to an educational orientation, a way of teaching. But attempts to read the Bible in this way might offer a teacher some guidance (or a picture of how she herself already approaches teaching, even if in some inchoate fashion), in the same way that Sarna helps a teacher using a historical approach and Leibowitz is an aid to teachers using a Jewish interpretive approach.

Even within personalization we can delineate a variety of approaches. One might be called "personalization with a psychological perspective." As one recent writer has put it, "with every story we study, we learn not only about what we are reading, but also about ourselves. In deciphering a text, we bring to the fore elements of our own being of which we may not always be conscious. We respond to our own questions and dilemmas." ${ }^{11}$ Reading biblical narratives "can serve as vehicles of insight into our own personalities as well as the dynamic tensions within our own families." ${ }^{2}$ The study of these texts serves a healing function-they can help our own "search for wholeness."63 Other personalization approaches suggest more of a political agenda; still others take a more

\footnotetext{
59 Ibid.

60 Ibid., 5.

61 Norman Cohen, Self, Struggle and Change (Woodstock, VT: Jewish Lights, 1997), 13.

62 Ibid., 14-15.

63 Ibid.
} 
religious/spiritual approach. All, however, share a common goal: to find the links between an individual person's life and the biblical text. ${ }^{64}$

\section{The "Big Ideas" of the Bible}

Looking again at various curriculum materials produced for the teaching of Bible, we see another orientation that also ultimately tries to find it own way into the issue of personal meaning and the Bible. This is seen, for example, in the Bible curriculum of the Melton Research Center, which we mentioned earlier in this article. We can see that the Melton materials were influenced by the contextual orientation as well as by the literary approach. Indeed, a comparison between Sarna's Understanding Genesis (which, as we noted earlier, was originally written for Melton) and the original Melton teacher's guide by Leonard Gardner ${ }^{65}$ shows the way that Gardner's work-very early on in Melton's history-introduced literary approaches and reduced the amount of Ancient Near Eastern comparisons drawn from Sarna's work. ${ }^{66}$

Gardner's writing is clearly aimed at the classroom teacher, and it appears that he (or perhaps better, he and the leadership of the Melton Center at that time) believed that a literary approach was more appropriate for classroom use. One need only compare Sarna's approach to the Joseph story with Gardner's to see the difference. In later years, the revised Melton curriculum materials written by Ruth Zielenziger lean even more heavily toward a literary orientation. ${ }^{67}$

But it would be inaccurate to term the Melton orientation as only or even primarily "literary." Instead of a concern for the literary features

64 For political readings, one might turn to Arthur Waskow's Godwrestling (New York: Schocken, 1978); or Judith Plaskow's feminist readings in Standing Again at Sinai (New York: Harper and Row, 1990). For a more "spiritual" approach, one could turn to Lawrence Kushner's God Was in This Place and I, I Did Not Know (Woodstock, VT: Jewish Lights, 1993).

65 Leonard Gardner, Genesis: The Teacher's Guide (New York: Melton Research Center, 1966).

66 See the discussion of the early years of the Melton Bible curriculum in Ruth Zielenziger, "A History of the Bible Program of the Melton Research Center with Special Reference to the Curricular Principles on Which It Is Based" (Ph.D. diss., Jewish Theological Seminary, 1989).

67 Ruth Zielenziger, Genesis: A New Teacher's Guide (New York: Melton Research Center, 1979). 
of the text alone, the curriculum might be characterized as having an "ideational" approach; that is, with a primary focus on answering the question, "What are the 'big ideas' that the Bible is expressing?" Or perhaps better, "What are the values of the Bible?" As Gardner put it:

There are two kinds of activities at which the lesson plans aim. The first is an analysis of the structure of the text. This requires a close reading of the text and a search for the particular devices which are employed: repetition, opening and closing statements; turning points or reversals....

The second kind of classroom activity at which we aim is to take each of the Bible stories as a metaphor which communicates an important idea. Thus in our analysis of the text, we search for the idea in its metaphorical expression. Once discovered, we work to make the idea clear in a more literal mode and to apply it to our own experience. ${ }^{68}$

From this passage, we see that although there is interest in the literary features of the text, the primary goal is to uncover the "idea in its metaphorical expression," to see the major moral and theological insights or ideas of the Bible. ${ }^{69}$ Examples of "big ideas" and values found in the curriculum are "the basic belief in the essential goodness of the universe" that we learn from the Creation story and "the endowment of man with moral autonomy and the stress upon the human aspect of evil" that we learn from the Cain and Abel story. ${ }^{70}$ Though it uses close reading of the text, this approach differs from the literary approach of Robert Alter and others because it seeks explicitly to extract a message from the text; ${ }^{71}$

68 Gardner, Genesis, 210.

69 Ibid., 211.

70 I've taken both examples from Sarna's Understanding Genesis, the original basis of the curriculum, which, despite its emphasis on a contextual framework and comparisons with the ancient Near Eastern sources, still asserts these basic ideas and values. The first example is found on p. 18, the second on p. 28. Looking at Gardner or Zielenziger, Genesis: A New Teacher's Guide, makes the case even more clearly.

71 There is, however, an interesting convergence between the Melton approach and that advocated by Zvi Adar, an influential Israeli educator of the same period. See Adar's Humanistic Values in the Bible (New York: Reconstructionist, 1967), and his article "The Teaching of the Bible in Israel and the Problem of Religious Education," in Scripta Hierosolymitana 13 (Jerusalem: Magnes, 1963). See Zielenziger, "A History of the Bible Program," 33-35. 
it is not framed moralistically or didactically, but rather represents an account of the various philosophical underpinnings of the biblical text.

\section{A Call to Action}

In the Melton materials we can discern another pedagogic orientation as well: the idea that learning Torah is intended to move people toward action-in this case, toward character development. How was character education supposed to occur? The most serious attempt to answer that question was by Burton Cohen and Joseph Schwab, in an article called "Practical Logic: Problems of Ethical Decision." 72 The authors argue that although "emotional factors may play a primary role in the development of character it seems likely that the role of intellect will not be an insignificant one."73 By arguing for the role of "advancing the student's character development through his intellect," ${ }^{4}$ the authors saw an opportunity to relate the normal work of schools (learning of subject matter) to questions of character and ethical development of individuals, a match that made a great deal of sense in the realm of Jewish education, where intellectual activities are framed by a larger religious agenda.

The method for accomplishing this was a set of exercises that related the ethical principles learned in studying Genesis to "life situations" through an approach that the authors called "practical logic," 75 a sophisticated method of ethical reasoning based on the notion that applying an ethical precept to a particular life situation is not a simple matter of learning a moral aphorism or idea and then behaving in the manner expected by this principle. Rather, the application of biblical

72 Burton Cohen and Joseph Schwab, "Practical Logic: Problems of Ethical Decision." The article originally appeared in The American Behavioral Scientist 8, no. 8 (April 1965) and was subsequently reprinted as an appendix to Gardner's Teacher's Guide. The page numbers in the references below refer to the reprint in Gardner. Ibid., 493.

74 Ibid.

75 Ibid., 494. Also see Burton Cohen, "The Teaching of Deliberation in the Jewish School," in Studies in Jewish Education, ed. Michael Rosenak (Jerusalem: Magnes, 1984), 2:122-35. For an interesting perspective on this type of approach to moral decision making, see Michael Oakeshott's “The Tower of Babel," in Rationalism in Politics and Other Essays (London: Methuen, 1962), 59-79. 
"lessons" to life involves a host of challenges to the individual, including (among the five "problems" discussed in the article): "the difficulty of identifying which ethical principle is applicable to a particular set of circumstances"76 and the fact that "a given concrete situation evokes from ... [a person's] catalogue of ethical precepts not one, but two or more apparently equally valid but apparently irreconcilable principles."77 Practical logic was an approach to dealing with the "relevance" of the Bible arguably more subtle and thoughtful than the way that that term has come to be used in educational parlance.

We can see this as related to a much older understanding within Judaism of studying Torah as a means to shaping action. Classical Jewish sources portray the purpose of study as leading a person toward observing the mitzvot, the commandments. ${ }^{78}$ Of course, within Jewish tradition there is a great deal of debate about the ultimate purposes of studying Torah-is the activity an end in itself? Does it have a purely intellectual purpose, a spiritual purpose, or is it intended to lead us to performing the commandments? There is a great deal of debate about these questions within the sources, but there is no doubt that one significant tradition-perhaps the dominant view-holds that there is a direct relationship between study and action. ${ }^{79}$ When we learn Torah, we are moved toward doing; study is not merely an intellectual activity.

Another more contemporary reflection of the Call to Action orientation is seen when teachers (in educational settings and in publication) focus on the call for social justice and social action reflected in the biblical text. What all these approaches share is the belief that one of the most important purposes of studying (and thus teaching) the biblical text is to shape the character and actions of its student, not just to

76 Cohen, "The Teaching of Deliberation," 494.

77 Ibid.

78 See, for example, Eliot Dorff, "Study Leads to Action," Religious Education, 75, no. 2 (March/April 1980): 171-192.

79 See the excellent discussion of these issues in Norman Lamm, Torah Lishmah: Torah for Torah's Sake in the Works of Rabbi Hayyim of Volozhin and His Contemporaries (Hoboken, NJ: Ktav, 1989). For the educational implications of the question, see the sophisticated analysis by Michael Rosenak, Roads to the Palace: Jewish Texts and Teaching (Providence: Berghahn, 1995), esp. 231-34; see also my discussion in Barry Holtz, Finding Our Way (New York: Schocken, 1990), 212-30. 
highlight for them the text's meanings over the ages and in their own time (whether historical, literary, traditional, personal, philosophical, or moralistic).

\section{Decoding and Translation}

One final orientation to teaching Bible is so elementary that it is easy to overlook, but so widespread that it is important not to ignore; we might call this the Decoding and Translation Orientation. This is simply the basic comprehension of the text-decoding (i.e., pronouncing) the Hebrew, translating from Hebrew, understanding the "facts," the characters' names, the plot details of stories, the nature of the laws, and the plain meaning of the words. Sometimes, it includes memorizing sections of the text or learning to sing the verses according to traditional cantillation notes. At its best, such an approach leads to the assimilation of vast comprehensive knowledge; at its worst, it can be mind-numbing and tedious.

For example, in Ruth Zielenziger's study of the early years of the Melton Bible curriculum, she describes the approach to teaching the Bible most commonly found in synagogue schools in the early $1950 \mathrm{~s},{ }^{80}$ one that had long been the main approach to Bible teaching dating from the days of the cheder. In the early part of the twentieth century, students would read the biblical text in Hebrew and translate it into Yiddish; later, under the influence of Samson Benderly's advocacy of the "natural method" (ivrit b'ivrit) for teaching Hebrew, students would read the text in biblical Hebrew and then (at least in theory) translate the text into modern Hebrew. The goal of using the natural method for learning Hebrew to improve biblical studies was never fully realized for most students, ${ }^{81}$ and for many the exercise of translating from biblical Hebrew to modern Hebrew only increased confusion. Furthermore, virtually no discussion of the meaning of the text occurred.

We might argue that the Decoding and Translation Orientation at its best is a temporary stage or tool in the service of other orientations.

80 See Zielenziger, "A History of the Bible Program," 38-43.

81 See the excellent discussion of Benderly and the natural method in Jonathan B. Krasner's recent The Benderly Boys and American Jewish Education (Waltham, MA: Brandeis University Press, 2011). Also my discussion of Bible teaching in the article referenced in note 31 above. 


\section{A "Map" of the Teaching of Bible}

Let me now summarize the discussion above with a conceptual map of our orientations for teaching Bible-that is, some of the core pedagogic stances toward the biblical text that teachers may hold or choose to hold.

Conceptual Map for Teaching the Bible

\begin{tabular}{|c|c|c|c|}
\hline Orientation & Key Element & Examples & Questions to Explore \\
\hline $\begin{array}{l}\text { 1. The } \\
\text { Contextual } \\
\text { Orientation }\end{array}$ & $\begin{array}{l}\text { Bible in the } \\
\text { context of its } \\
\text { own times. }\end{array}$ & $\begin{array}{l}\text { Academic } \\
\text { research } \\
\text { on Bible-- } \\
\text { historically- } \\
\text { oriented } \\
\text { studies } \\
\text { (Sarna, } \\
\text { Understanding } \\
\text { Genesis; } \\
\text { Brettler, How } \\
\text { to Read the } \\
\text { Jewish Bible). }\end{array}$ & $\begin{array}{l}\text { How would people in bibli- } \\
\text { cal times have understood } \\
\text { these texts? What can } \\
\text { the Ancient Near Eastern } \\
\text { context teach us about un- } \\
\text { derstanding the Bible, and } \\
\text { what, in turn, can the Bible } \\
\text { teach us about that world? } \\
\text { How can the discoveries } \\
\text { of archeology, geography, } \\
\text { and the knowledge of other } \\
\text { ancient Semitic languages } \\
\text { uncover the meaning of the } \\
\text { Bible in its own time? }\end{array}$ \\
\hline $\begin{array}{l}\text { 2. The } \\
\text { Literary } \\
\text { Criticism } \\
\text { Orientation }\end{array}$ & \begin{tabular}{|l} 
Tools of \\
modern and \\
postmodern \\
literary criti- \\
cism applied \\
to the Bible.
\end{tabular} & $\begin{array}{l}\text { Academic } \\
\text { research } \\
\text { on Bible- } \\
\text { literary } \\
\text { critical studies } \\
\text { (e.g. Alter; } \\
\text { Greenstein; } \\
\text { sometimes } \\
\text { in textbooks } \\
\text { such as } \\
\text { Being Torah, } \\
\text { Melton Bible } \\
\text { Curriculum). }\end{array}$ & $\begin{array}{l}\text { How can we apply the skills } \\
\text { of literary criticism to the } \\
\text { Bible, reading the Bible } \\
\text { the way we would read any } \\
\text { great work of literature? } \\
\text { How do the general tools } \\
\text { of literary criticism-such } \\
\text { as close reading of the } \\
\text { text, attention to detail, } \\
\text { shifts of language and tone, } \\
\text { metaphors, etc.-help us } \\
\text { understand the Bible? How } \\
\text { do the specific literary fea- } \\
\text { tures of the Bible- - such as } \\
\text { repeating words and roots, } \\
\text { "type scenes," repeated } \\
\text { dialogue, etc.-reveal the } \\
\text { meaning of biblical texts? }\end{array}$ \\
\hline
\end{tabular}




\begin{tabular}{|c|c|c|c|}
\hline Orientation & Key Element & Examples & Questions to Explore \\
\hline $\begin{array}{l}\text { 3. Parshanut: } \\
\text { The Jewish } \\
\text { Interpretive } \\
\text { Orientation }\end{array}$ & $\begin{array}{l}\text { Exploration of } \\
\text { classical com- } \\
\text { mentators' } \\
\text { understanding } \\
\text { of Bible. }\end{array}$ & $\begin{array}{l}\text { Nehama } \\
\text { Leibowitz. }\end{array}$ & $\begin{array}{l}\text { How do our rabbinic } \\
\text { ancestors interpret the } \\
\text { gaps and "difficulties" in } \\
\text { biblical texts? How do we } \\
\text { make sense of the conflicts } \\
\text { among the interpreters? }\end{array}$ \\
\hline $\begin{array}{l}\text { 4. Moralistic- } \\
\text { Didactic } \\
\text { Orientation }\end{array}$ & $\begin{array}{l}\text { Exploring } \\
\text { the Bible as } \\
\text { a source of } \\
\text { moral lessons. }\end{array}$ & $\begin{array}{l}\text { Textbooks } \\
\text { (e.g. A Child's } \\
\text { Bible). }\end{array}$ & $\begin{array}{l}\text { What is the moral lesson } \\
\text { that the Bible teaches us? } \\
\text { What's the "message" of } \\
\text { the text? } \\
\text { How do I sum up a text's } \\
\text { message and meaning? }\end{array}$ \\
\hline $\begin{array}{l}\text { 5.Personali- } \\
\text { zation }\end{array}$ & $\begin{array}{l}\text { The Bible as a } \\
\text { source of per- } \\
\text { sonal meaning } \\
\text { in people's } \\
\text { lives. }\end{array}$ & $\begin{array}{l}\text { Some curricu- } \\
\text { lar materials; } \\
\text { found in } \\
\text { contemporary } \\
\text { popular works } \\
\text { on the Bible } \\
\text { (Visotzsky; } \\
\text { Norman Co- } \\
\text { hen; Waskow; } \\
\text { Pitzele). } \\
\end{array}$ & $\begin{array}{l}\text { How can the Bible speak } \\
\text { to us, psychologically and } \\
\text { spiritually? What does it } \\
\text { mean to "make meaning" } \\
\text { of biblical texts for our } \\
\text { personal lives? } \\
\text { How do we make the Bible } \\
\text { "relevant" for our students? }\end{array}$ \\
\hline $\begin{array}{l}\text { 6. The } \\
\text { Ideational } \\
\text { Orientation }\end{array}$ & $\begin{array}{l}\text { The Bible as a } \\
\text { repository of } \\
\text { core ideas and } \\
\text { values. }\end{array}$ & $\begin{array}{l}\text { Melton Bible } \\
\text { curriculum. }\end{array}$ & $\begin{array}{l}\text { How do we help students } \\
\text { become intellectual readers } \\
\text { and interpreters? What are } \\
\text { the complex ideas embed- } \\
\text { ded in the Bible? }\end{array}$ \\
\hline $\begin{array}{l}\text { 7. The Bible } \\
\text { Leads to } \\
\text { Action } \\
\text { Orientation }\end{array}$ & $\begin{array}{l}\text { Study leads us } \\
\text { to performing } \\
\text { command- } \\
\text { ments, ethical } \\
\text { behavior, } \\
\text { tikkun olam. }\end{array}$ & $\begin{array}{l}\text { Textbooks of } \\
\text { various sorts, } \\
\text { e.g. Sefer } \\
\text { HaHinukh, } \\
\text { modern books } \\
\text { on the Bible's } \\
\text { relevance for } \\
\text { practice. }\end{array}$ & $\begin{array}{l}\text { What mitzvot do we learn } \\
\text { about from the Bible? } \\
\text { How do we take the Bible } \\
\text { and apply it to issues of } \\
\text { contemporary life? How } \\
\text { does the Bible help guide } \\
\text { our ethical behavior? }\end{array}$ \\
\hline $\begin{array}{l}\text { 8. The Deco- } \\
\text { ding and } \\
\text { Translation } \\
\text { Orientation }\end{array}$ & $\begin{array}{l}\text { Decoding the } \\
\text { Hebrew and } \\
\text { comprehend- } \\
\text { ing the basics. }\end{array}$ & $\begin{array}{l}\text { Older text- } \\
\text { books. }\end{array}$ & $\begin{array}{l}\text { How do we read aloud (de- } \\
\text { code) and translate biblical } \\
\text { Hebrew? What tools do } \\
\text { students need to learn to } \\
\text { facilitate these skills (gram- } \\
\text { mar, vocabulary, etc.)? }\end{array}$ \\
\hline
\end{tabular}




\section{Conclusion}

In the end, of course, our "map" is only partially complete. It should be viewed not as a theoretical construct of pedagogical approaches based on philosophical positions, but rather as a kind of "middle range" representation of current Bible teaching approaches, covering some of the most commonly found examples of the way teachers think about-and practice-contemporary Bible pedagogy. This map is meant to be a heuristic device; it has the advantage of being compact and the disadvantage of being inattentive to some of the subtle distinctions that might be adumbrated.

Outlining the map is not the end of our task, for many questions remain about the use of this theoretical construct in practice. What are the practical implications of having such a map? In what way might it guide or influence Bible teachers or those responsible for working with teachers? How does the map of orientations relate to the question of a teacher's goals? In helping to organize teachers' thinking, the map may let teachers have a better sense of why they are doing what they are doing.

Finally, understanding orientations to the Bible also invites teachers to see the perspectives of the particular students in their classes and the characteristics of particular texts. Not every orientation will speak to every student. And not every text will be served equally well by any given orientation. Having this conceptual tool allows us to think harder about the particulars of our work, make sense of what we are already doing, and focus on the practices that best illuminate the Bible for a variety of students and using a wide range of biblical texts. 